\title{
A CLINICAL STUDY TO COMPARE THE EFFICACY OF TRICHLOROACETIC ACID PEEL VERSUS TRETINOIN PEEL IN THE TREATMENT OF MELASMA
}

\author{
Sanjana A. S1, Rajendra Okade ${ }^{2}$
}

${ }_{1}^{1}$ Assistant Professor, Department of Dermatology, Venereology and Leprosy, BGS Global Institute of Medical Sciences, Bengaluru, India. 2Professor, Department of Dermatology, Venereology and Leprosy, BGS Global Institute of Medical Sciences, Bengaluru, India.

\begin{tabular}{l}
\hline ABSTRACT \\
BACKGROUND \\
varied results. The aim of this study is to compare the therapeutic response of melasma in south Indian patients when treated by \\
$20 \%$ trichloroacetic acid peel and 1\% tretinoin yellow peel in a split-face study.
\end{tabular}

\section{MATERIALS AND METHODS}

An experimental study was done on hundred patients over a period of 1 year between December 2014 and November 2015. Patients were selected as per the inclusion and exclusion criteria. The face was arbitrarily divided into right and left halves. Right half was treated with Obagi blue peel containing trichloroacetic acid $20 \%$ and left half with yellow peel containing tretinoin $0.1 \%$. A total of 4 sittings of peel at an interval of four weeks was done for all the patients. Clinical colour photographs were taken before the start of each sitting of peel and at followup.

\section{RESULTS}

There were 100 patients included in the study, 78 were females and 22 were males. Epidermal melasma accounts for $75 \%$ and mixed melasma 25\%. Duration of melasma ranged from 1 month to 60 months with mean duration of 34 months. The percentage reduction of MASI score in mixed melasma was 34.6\% in TCA group and 33.7\% in Tretinoin group. The percentage reduction of MASI score in epidermal melasma was $72.9 \%$ and $70.2 \%$ in TCA group and Tretinoin group.

\section{CONCLUSION}

The therapeutic response of melasma to TCA peel and Tretinoin peel is similar in our study. The response to treatment was significantly better in the epidermal melasma patients when compared to mixed melasma patients with either of the peel agents.

\section{KEYWORDS}

Melasma, Chemical Peels, Trichloroacetic Acid, Tretinoin Peel.

HOW TO CITE THIS ARTICLE: Sanjana AS, Okade R. A clinical study to compare the efficacy of trichloroacetic acid peel versus tretinoin peel in the treatment of melasma. J. Evolution Med. Dent. Sci. 2018;7(03):351-355, DOI: 10.14260/jemds/2018/78

\section{BACKGROUND}

Melasma is the most common pigmentary dermatoses affecting either sex characterised by brownish black patches symmetrically distributed over cheeks, forehead, nose and chin. [1]

Chemical peel have been used in the treatment armamentarium of melasma. However, comparative studies with TCA and yellow peels have not been reported in Indian patients (Fitzpatrick skin types 4 to 5 ) with subjective and objective methods of evaluation.

\section{MATERIALS AND METHODS}

An experimental study was done on 100 patients. Sample size was selected as 100 patients for convenience. This study was conducted on outpatient basis for a period of 1 year from $1^{\text {st }}$ December 2014 to $30^{\text {th }}$ November 2015 after obtaining ethical clearance from the Institutional Ethics Committee.

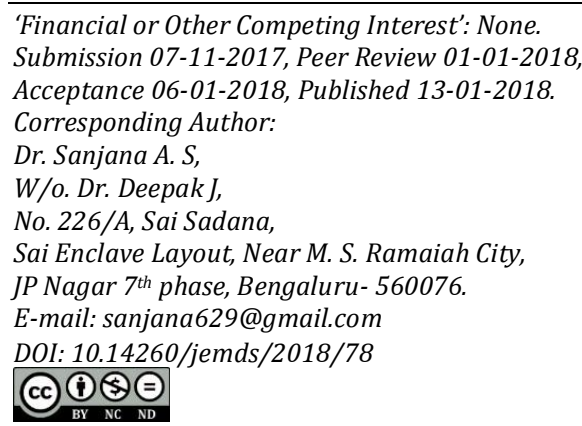

The patients with epidermal and mixed melasma with minimum melasma area index of 10 were included in the study. Pregnant and lactating patients, patients with history of keloid tendency or hypertrophic scar, active infection, patients with unrealistic expectations, patients on oral contraceptive pills and patients with systemic or other skin disease were excluded from the study.

MASI was calculated depending on homogeneity of melasma over forehead, right and left malar area and chin. Each area was given a numerical value $(0-4)$. The proportion of area of each site with respect to total area of face was determined. Percentage for forehead (F) 30\%, right malar (30\%), left malar area (30\%) and chin (C) $10 \%$ was considered. The sum of severity of darkness $(0-4)$ and homogeneity (0-4) of melasma was multiplied by the numerical value and percentage of each area. These values were then added to obtain MASI score by single blinded dermatologist.

- $\quad \mathrm{MASI}=0.3(\mathrm{DF}+\mathrm{HF}) \mathrm{AF}+0.3(\mathrm{DMR}+\mathrm{HMR}) \mathrm{AMR}+0.3$ $(\mathrm{DML}+\mathrm{HML}) . \mathrm{AML}+0.1(\mathrm{DC}+\mathrm{HC}) \mathrm{AC}$.

- DF- Darkness Forehead.

- HF- Homogeneity Forehead.

- AF- Area Forehead.

- DMR- Darkness Right Malar.

- HMR- Homogeneity Right Malar.

A detailed history and clinical examination of all the patients was undertaken. Patients were examined under 
natural light and epidermal melasma with light brown colour and mixed melasma were also selected for the study. Biopsy and histopathological examination was done in doubtful cases. MASI score was calculated for all patients. A minimum MASI score of 10 was included in the study. A written informed consent was taken for all the patients. A pre-peel programme consisting of sunscreen with minimum SPF 26 was advised during daytime and glycolic acid $12 \%$ cream during night for a period of two weeks.

A total of 4 sittings of peel at an interval of four weeks was done for all the patients. Clinical colour photographs were taken before start of each sitting of peel and at followup. Facial regions were divided as right and left halves, keeping an arbitrary line joining midpoint of glabella and tip of nose extending upwards near hair margin and downwards up to chin. Right half was treated with Obagi blue peel containing trichloroacetic acid $20 \%$ and left half with yellow peel containing tretinoin $0.1 \%$. After degreasing the face, respective peels were applied in anatomical sites sequentially from forehead, temple, cheeks, nose and perioral. Firstly, Obagi blue peel was applied over right half and thereafter yellow peel to the left half of face. Obagi peel was left over for a period of five minutes and thereafter neutralised with normal saline. The yellow peel was left over for 30 minutes and cleaned with normal saline. Post peel patients were advised to use sunscreen and $12 \%$ glycolic acid cream at night.

The improvement in pigmentation was objectively assessed using MASI score before the start of each sitting of peel. Subjective improvement in each patient was graded as no improvement with score 0 , mild improvement as score 1 , moderate improvement as score 2 and good improvement as score 3. Any secondary changes or side effects were noted after each sitting. Monthly follow-up for 2 months after completion of 4 sittings of peel was done for all the patients.

\section{Statistical Analysis}

The data obtained was statistically analysed using SPSS software version 20. Student's paired t-test and Epi Info software was used to calculate for any significant difference in the response to each of the different peel and to calculate statistical significance in response to both the peels between mixed and epidermal variants.

\section{RESULTS}

There were 100 patients included in the study, 78 were females and 22 were males. Epidermal melasma accounts for $75 \%$ and mixed melasma 25\%. Duration of melasma ranged from 1 month to 60 months with mean duration of 34 months. No significant precipitating factor was noticed like pregnancy, drug intake including oral contraceptives or sun exposure.

\section{Objective Response}

Objective response was determined separately for 2 groups of patients, namely mixed melasma group and epidermal melasma group. The initial MASI score was determined for each of the patients and an average was taken. The initial prepeel average MASI score for mixed melasma group was 30.3 and epidermal group was 23.88 .

The MASI score was calculated in each of the patient in both mixed melasma and epidermal melasma groups after each sitting of TCA peel and Tretinoin peel. The average MASI score was calculated for both groups separately for TCA peel (Table 1) and Tretinoin peel (Table 2).

\begin{tabular}{|c|c|}
\hline MASI score & Mean (SD) \\
\hline $\begin{array}{l}\text { Mean (SD) MASI score } \\
\text { pre-peel mixed }\end{array}$ & $30.3(+/-1.97)$ \\
\hline $\begin{array}{l}\text { MASI score after 1st sitting with } \\
\text { TCA peel in mixed melasma }\end{array}$ & $28.5(+/-1.76)$ \\
\hline $\begin{array}{l}\text { MASI score after } 2 \text { nd sitting with } \\
\text { TCA peel in mixed melasma }\end{array}$ & $25.9(+/-1.51)$ \\
\hline $\begin{array}{l}\text { MASI score after 3rd sitting with } \\
\text { TCA peel in mixed melasma }\end{array}$ & $23.5(+/-1.32)$ \\
\hline $\begin{array}{l}\text { MASI score after 4th sitting with } \\
\text { TCA peel in mixed melasma }\end{array}$ & $19.8(+/-1.18)$ \\
\hline MASI score pre-peel epidermal & $23.88(+/-1.36)$ \\
\hline $\begin{array}{c}\text { MASI score after 1st sitting } \\
\text { with TCA peel in epidermal melasma }\end{array}$ & $19.6(+/-1.16)$ \\
\hline $\begin{array}{l}\text { MASI score after 2nd sitting } \\
\text { with TCA peel in epidermal melasma }\end{array}$ & $14.2(+/-1.02)$ \\
\hline $\begin{array}{l}\text { MASI score after } 3^{\text {rd }} \text { sitting } \\
\text { with TCA peel in epidermal melasma }\end{array}$ & $10.5(+/-0.66)$ \\
\hline $\begin{array}{c}\text { MASI score after } 4 \text { th sitting } \\
\text { with TCA peel in } \\
\text { epidermal melasma }\end{array}$ & $6.4(+/-0.28)$ \\
\hline
\end{tabular}

\begin{tabular}{|c|c|}
\hline $\begin{array}{c}\text { Pre-peel MASI score in mixed } \\
\text { melasma }\end{array}$ & $30.3(+/-1.97)$ \\
\hline $\begin{array}{c}\text { MASI score after 1st sitting with } \\
\text { Tretinoin peel in mixed melasma }\end{array}$ & $28.3(+/-1.77)$ \\
\hline $\begin{array}{c}\text { MASI score after 2nd sitting with } \\
\text { Tretinoin peel in mixed melasma }\end{array}$ & $26.8(+/-1.42)$ \\
\hline $\begin{array}{c}\text { MASI score after 3rd sitting with } \\
\text { Tretinoin peel in mixed melasma }\end{array}$ & $24.9(+/-1.38)$ \\
\hline $\begin{array}{c}\text { MASI score after 4th sitting with } \\
\text { Tretinoin peel in mixed melasma }\end{array}$ & $20.1(+/-1.18)$ \\
\hline $\begin{array}{c}\text { Mean (SD) pre-peel MASI score in } \\
\text { epidermal melasma }\end{array}$ & $23.88(+/-1.38)$ \\
\hline $\begin{array}{c}\text { MASI score after 1st sitting with } \\
\text { Tretinoin peel in epidermal melasma }\end{array}$ & $18.3(+/-1.08)$ \\
\hline $\begin{array}{c}\text { MASI score after 2nd sitting with } \\
\text { Tretinoin peel in epidermal melasma }\end{array}$ & $13.9(+/-0.98)$ \\
\hline $\begin{array}{c}\text { MASI score after 3rd sitting with } \\
\text { Tretinoin peel in epidermal melasma }\end{array}$ & $10.2(+/-0.69)$ \\
\hline $\begin{array}{c}\text { MASI score after 4th sitting with } \\
\text { Tretinoin peel in epidermal melasma }\end{array}$ & $7.1(+/-0.32)$ \\
\hline Table 1b. Tretinoin Peel \\
\hline
\end{tabular}

\begin{tabular}{|c|c|c|}
\hline $\begin{array}{c}\text { MASI score mixed } \\
\text { melasma TCA peel= } \\
19.8\end{array}$ & $\begin{array}{c}\text { MASI score mixed } \\
\text { melasma Tretinoin } \\
\text { peel }=20.1\end{array}$ & $\begin{array}{c}\text { P value= } \\
0.0702\end{array}$ \\
\hline $\begin{array}{c}\text { MASI score epidermal } \\
\text { melasma TCA peel= } \\
6.4\end{array}$ & $\begin{array}{c}\text { MASI score epidermal } \\
\text { melasma Tretinoin } \\
\text { peel }=7.1\end{array}$ & $\begin{array}{c}\text { P value }= \\
0.05829\end{array}$ \\
\hline $\begin{array}{c}\text { MASI score mixed } \\
\text { melasma TCA peel= } \\
19.8\end{array}$ & $\begin{array}{c}\text { MASI score epidermal } \\
\text { melasma TCA peel= } 6.4\end{array}$ & $\begin{array}{c}\text { P value } \\
<0.0001\end{array}$ \\
\hline $\begin{array}{c}\text { MASI score mixed } \\
\text { melasma Tretinoin } \\
\text { peel= } 20.1\end{array}$ & $\begin{array}{c}\text { MASI score epidermal } \\
\text { melasma Tretinoin } \\
\text { peel }=7.1\end{array}$ & $\begin{array}{c}\text { P value } \\
<0.0001\end{array}$ \\
\hline $\begin{array}{c}\text { Table 2. Comparison of MASI Score after 4 Cycles of Peel } \\
\text { between TCA and Tretinoin Peels }\end{array}$ \\
\hline \multicolumn{3}{|c}{} \\
\hline
\end{tabular}




\section{Subjective Response}

Subjective response of patients who were treated with TCA peel, who were diagnosed to have mixed melasma was documented. The score 0 indicates no subjective improvement as perceived by the patient, score 1 indicates mild improvement, score 2 indicates moderate improvement and a score of 3 indicates good improvement. The number of patients with each of these scores after each sitting is documented in Table 3.

\begin{tabular}{|c|c|c|c|}
\hline $\begin{array}{c}\text { Subjective } \\
\text { Score 0 [No. of } \\
\text { patients (\%)] }\end{array}$ & $\begin{array}{c}\text { Subjective } \\
\text { pore 1 [No. of } \\
\text { patients (\%)] }\end{array}$ & $\begin{array}{c}\text { Subjective } \\
\text { Score 2 [No. of } \\
\text { patients (\%)] }\end{array}$ & $\begin{array}{c}\text { Subjective } \\
\text { Score 3 [No. of } \\
\text { patients (\%)] }\end{array}$ \\
\hline $\begin{array}{c}\text { 1st Sitting } \\
\text { 17(68.0\%) }\end{array}$ & $7(28.0 \%)$ & $1(4.0 \%)$ & 0 \\
\hline $\begin{array}{c}\text { 2nd Sitting } \\
16(64.0 \%)\end{array}$ & $6(24.0 \%)$ & $3(12.0 \%)$ & 0 \\
\hline $\begin{array}{c}\text { 3rd Sitting } \\
15(60.0 \%)\end{array}$ & $7(28.0 \%)$ & $3(12.0 \%)$ & 0 \\
\hline $\begin{array}{c}\text { 4th Sitting } \\
\text { 15(60.0\%) }\end{array}$ & $6(24.0 \%)$ & $4(16.0 \%)$ & 0 \\
\hline $\begin{array}{c}\text { Follow-Up } \\
\text { 15(60.0\%) }\end{array}$ & $7(28.0 \%)$ & $3(12.0 \%)$ & 0 \\
\hline \multicolumn{4}{|c|}{ Table 3 } \\
\hline
\end{tabular}

Similarly, subjective response in patients with epidermal melasma who were treated with TCA peel was documented (Table 4).

\begin{tabular}{|c|c|c|c|}
\hline $\begin{array}{c}\text { Subjective } \\
\text { Score 0 [No. of } \\
\text { patients (\%)] }\end{array}$ & $\begin{array}{c}\text { Subjective } \\
\text { Score 1 [No. of } \\
\text { patients (\%)] }\end{array}$ & $\begin{array}{c}\text { Subjective } \\
\text { Score 2 [No. of } \\
\text { patients (\%)] }\end{array}$ & $\begin{array}{c}\text { Subjective } \\
\text { Score 3 [No. of } \\
\text { patients (\%)] }\end{array}$ \\
\hline $\begin{array}{c}\mathbf{1}^{\text {st }} \text { Sitting } \\
10(13.3 \%)\end{array}$ & $30(40.0 \%)$ & $26(34.7 \%)$ & $9(12.0 \%)$ \\
\hline $\begin{array}{c}\mathbf{2}^{\text {nd }} \text { Sitting } \\
6(8.0 \%)\end{array}$ & $17(22.7 \%)$ & $28(37.3 \%)$ & $14(18.7 \%)$ \\
\hline $\begin{array}{c}\mathbf{3}^{\text {rd }} \text { Sitting } \\
4(5.3 \%)\end{array}$ & $7(9.3 \%)$ & $30(40.0 \%)$ & $34(45.3 \%)$ \\
\hline $\begin{array}{c}\mathbf{4}^{\text {th }} \text { Sitting } \\
2(2.6 \%)\end{array}$ & $5(6.7 \%)$ & $15(20.0 \%)$ & $53(70.6 \%)$ \\
\hline $\begin{array}{c}\text { Follow-Up } \\
2(2.6 \%)\end{array}$ & $4(5.3 \%)$ & $16(21.3 \%)$ & $53(70.6 \%)$ \\
\hline \multicolumn{4}{|c|}{ Table 4 } \\
\hline
\end{tabular}

The subjective response to Tretinoin peel was assessed and documented for mixed melasma and epidermal melasma in Table 5 and Table 6 respectively.

\begin{tabular}{|c|c|c|c|}
\hline Subjective & Subjective & Subjective & Subjective \\
\hline $\begin{array}{c}\text { Score } 0[\text { [No. of } \\
\text { patients (\%)] }\end{array}$ & $\begin{array}{l}\text { Score } 1 \text { [No. of } \\
\text { patients (\%)] }\end{array}$ & $\begin{array}{l}\text { Score } 2 \text { [No. of } \\
\text { patients (\%)] }\end{array}$ & $\begin{array}{l}\text { Score } 3 \text { [No. of } \\
\text { patients (\%)] }\end{array}$ \\
\hline $\begin{array}{l}\text { 1st Sitting } \\
19(76.0 \%)\end{array}$ & $4(16.0 \%)$ & $2(8.0 \%)$ & 0 \\
\hline $\begin{array}{l}2^{\text {nd }} \text { Sitting } \\
17(68.0 \%)\end{array}$ & $5(20.0 \%)$ & $3(12.0 \%)$ & 0 \\
\hline $\begin{array}{l}\text { 3rd Sitting } \\
15(60.0 \%)\end{array}$ & $7(28.0 \%)$ & $3(12.0 \%)$ & 0 \\
\hline $\begin{array}{l}4^{\text {th }} \text { Sitting } \\
13(52.0 \%)\end{array}$ & $8(32.0 \%)$ & $4(16.0 \%)$ & 0 \\
\hline $\begin{array}{l}\text { Follow-Up } \\
13(52.0 \%)\end{array}$ & $8(32.0 \%)$ & $4(16.0 \%)$ & 0 \\
\hline \multicolumn{4}{|c|}{ Table 5} \\
\hline
\end{tabular}

\begin{tabular}{|c|c|c|c|}
\hline $\begin{array}{c}\text { Subjective } \\
\text { Score 0 } \\
\text { [No. of patients } \\
(\%)]\end{array}$ & \begin{tabular}{|c|} 
Subjective \\
Score 1 \\
{$[$ No. of patients } \\
$(\%)]$ \\
\end{tabular} & \begin{tabular}{|c|} 
Subjective \\
Score 2 \\
{$[$ No. of } \\
patients (\%)] \\
\end{tabular} & $\begin{array}{c}\text { Subjective } \\
\text { Score } 3 \\
{[\text { No. of }} \\
\text { patients (\%)] }\end{array}$ \\
\hline $\begin{array}{c}\text { 1 }^{\text {st }} \text { Sitting } 9 \\
(12.0 \%)\end{array}$ & $37(49.3 \%)$ & $16(21.3 \%)$ & 13 (17.3\%) \\
\hline $\begin{array}{c}2^{\text {nd }} \text { Sitting } 5 \\
(6.7 \%)\end{array}$ & $24(32.0 \%)$ & $26(34.7 \%)$ & $20(26.7 \%)$ \\
\hline $\begin{array}{c}\text { 3 }^{\text {rd }} \text { Sitting } 4 \\
(5.3 \%)\end{array}$ & $9(12.0 \%)$ & $25(33.3 \%)$ & 37 (49.3\%) \\
\hline $\begin{array}{c}4^{\text {th }} \text { Sitting } 2 \\
(2.7 \%)\end{array}$ & 8 (10.7\%) & $12(16.0 \%)$ & $53(70.6 \%)$ \\
\hline $\begin{array}{c}\text { Follow-Up } 2 \\
(2.7 \%)\end{array}$ & 8 (10.7\%) & $12(16.0 \%)$ & $53(70.6 \%)$ \\
\hline
\end{tabular}
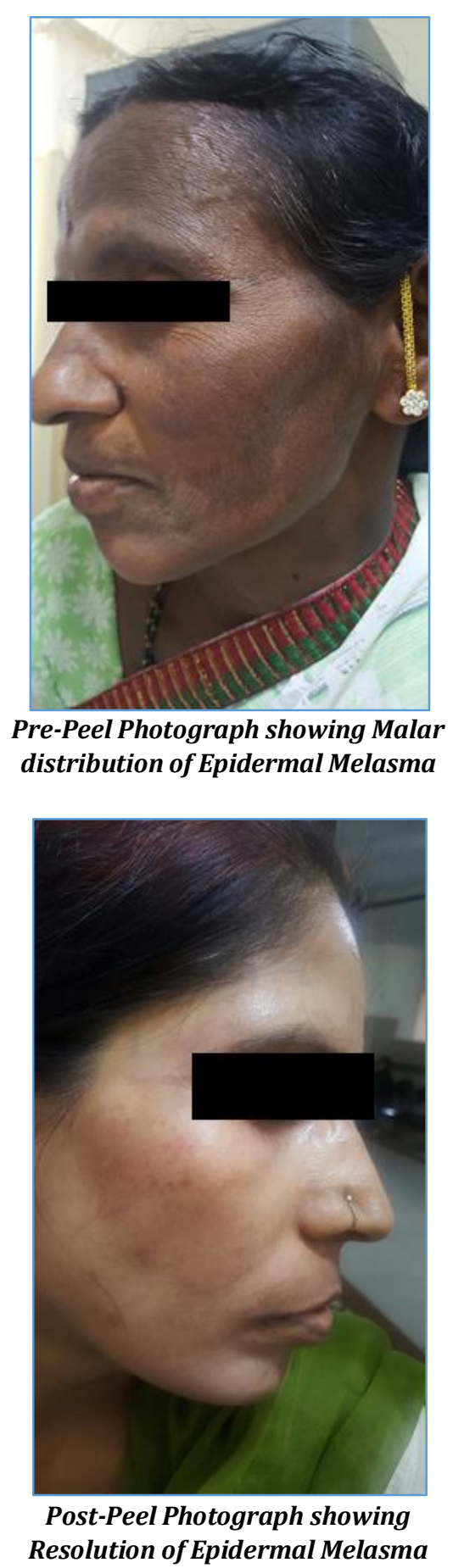
Side effects- Nine patients had rashes with pruritus on the side of the face, where TCA peel treatment was done. Among these patients 2 had mixed melasma and 7 had epidermal melasma. Rashes were transient and disappeared promptly with treatment. No side effect was noted with the Tretinoin peel.

Relapse- There was no relapse in either group of treatments during the follow-up.

\section{DISCUSSION}

Melasma is a common pigmentary disorder that manifests as symmetric hyperpigmented macules and patches on the face. Melasma is more common in women of child-bearing age,[2] although men also suffer from the condition and account for $10 \%$ of the cases.[3] Melasma affects all races, but is observed more frequently among individuals with skin type IV - VI, especially in women of Hispanic, Caribbean and Asian origin, who live in areas of intense ultraviolet radiation. ${ }^{[4]}$ Genetic predisposition, ultraviolet (UV) radiation exposure, hormonal factors such as female sex hormones and thyroid disease, pregnancy and drugs like phenytoin are the known risk factors. Factors involved in the pathogenesis of melasma include various vascular growth factors, genetic factors and the role of H19, inducible nitric oxide synthase (iNOS) and Wnt pathway modulator genes. Kim et al carried out a histological study to evaluate the vascular characteristics of melasma.[5] They found that vascular endothelial growth factor was increased in lesional skin in melasma signifying increased vascularisation. Mahmoud et al studied the impact of long-wavelength ultraviolet A (UVA) and visible light on melanocompetent skin.[6] They found that both UVA and visible light were able to increase pigmentation, especially in patients with dark skin (skin type IV - VI).

There are three clinical patterns- centrofacial, malar and mandibular- depending upon the area of localisation.[1] Histologically, melasma is divided into three types: epidermal, dermal and mixed.[7] Wood's light causes intensification of pigmentation in epidermal-type melasma, but does not enhance the pigmentation in the dermal type. A combination of epidermal and dermal macules is recognised as the mixed type.[8]

Hydroquinone (HQ) and triple combination creams (TCCs) remain the gold standard of treatment. There have been concerns about the side effects and long-term safety of HQ; hence, the need to develop alternate treatment options. Current treatment modalities include kojic acid, azelaic acid, arbutin, ascorbic acid, chemical peels and lasers. Newer formulations that are being tried include tranexamic acid (TA), rucinol (4-n-butylresorcinol), oligopeptides silymarin and orchid extracts. Various botanical extracts that have been tried in melasma are grape seed extract, pycnogenol, aloesin, green tea extracts, coffee berry, soy and licorice extract.

Chemical peeling aims at production of controlled chemical burns of epidermis and/ or dermis resulting in exhalation and subsequent resurfacing of the epidermis and remodelling of collagen and elastic fibres with deposition of glycosaminoglycans in dermis. Both the agents used in this study, TCA $20 \%$ and Tretinoin $1 \%$ are superficial peels. Superficial peels are defined as those causing injury to the dermis and dermoepidermal interface. Medium depth peels are those that penetrate to the papillary or reticular dermis $(35 \%-50 \%$ TCA $)$. Deep peels are those that cause destruction into the reticular dermis, but have longer healing time and more serious complications. [9]

Kimbrough-Green et al[10] reported a higher age of onset (44 years) of melasma in their study of Black patients. In our study the average age of melasma onset is 31.9 years, which is comparable to other Indian studies. Kimbrough-Green et al[11] in Black women and Griffiths et al[11] in Caucasian women observed epidermal-type melasma in 43\% and 94\% of patients, respectively. In our study, $75 \%$ patients had epidermal melasma. Although, melasma is predominantly noticed in female patients in various studies, our study comprised of $22 \%$ male patients.

Kalla et al[12] has done a study comparing the efficacy of glycolic acid peel and TCA peel, and has showed comparable results on subjective scores given by patients; however, objective scoring system like MASI score was not used in that study. In a recent study[13] from Pakistan, chemical peeling was done in group A (GA 50\%) and group B (TCA 20\%) with 25 patients in each group. The mean score of response calculated for both the groups revealed better overall clinical response in TCA group than in GA group, but this difference was statistically insignificant ( $p>0.05$ ). In another study, $1 \%$ tretinoin peel versus 70\% GA at weekly intervals was carried out in 10 patients in a split-face trial. A significant decrease in the modified MASI from baseline to 12 weeks was observed on both facial sides ( $\mathrm{p}<0.001)$. The study concluded that serial $1 \%$ tretinoin peel is as effective a therapy for melasma as chemical peeling with $70 \% \mathrm{GA}$.

In our study, the results were objectively assessed by MASI score for mixed melasma and epidermal melasma separately. The final MASI score in mixed melasma was 19.8 in TCA group and 20.1 in Tretinoin group. There was no statistical significance between two peels in the mixed melasma group $(p=0.0702)$. Similarly, the final MASI score in epidermal melasma was 6.4 and 7.1 in TCA group and Tretinoin group respectively and the difference was statistically insignificant ( $\mathrm{p}=0.05829)$.

However, within the TCA group the final MASI score in epidermal melasma (6.4) was significantly lesser when compared to mixed melasma (19.8) patients [p $<0.0001]$. Similarly, within the Tretinoin group, the MASI score was significantly lesser in epidermal melasma (7.1) group compared to mixed melasma group (20.1) [p $<0.0001$ ].

Subjective scoring done after final sitting of the peel showed that the score in the TCA group in mixed melasma patients was either 0 or 1 in $84 \%$ and 2 or 3 in $16 \%$ of patients only, whereas it was either 0 or 1 in $7.9 \%$ patients and the score was 2 or 3 in $91.9 \%$ in epidermal melasma patients. Thus, only $16 \%$ of patients had satisfactory or good improvement in mixed melasma patients, whereas in epidermal melasma it was satisfactory or good improvement in $91.9 \%$ patients. The subjective score in the epidermal melasma group was satisfactory or good in statistically significant number of patients when compared to mixed melasma patients $(\mathrm{p}<0.0001)$. The subjective scoring in the Tretinoin group showed similar results. The score was satisfactory or good in significantly higher number of patients in epidermal melasma patients when compared to mixed melasma patients, $86.6 \%$ and $16 \%$ respectively $(\mathrm{p}<0.0001)$. 


\section{CONCLUSION}

The therapeutic response of melasma to TCA peel and Tretinoin peel is similar in our study. The response to treatment was significantly better in the epidermal melasma patients when compared to mixed melasma patients with either of the peel agents. Tretinoin peel with additional advantages of facial rejuvenation, anti-aging effect and no side effects like rashes or itching may be the preferred peeling agent for treatment of melasma.

\section{REFERENCES}

[1] Lapeere H, Borne B, Schepper S, et al. Hypomelanosis and hypermelanosis. In: Wolff K, Goldsmith LA, Katz SI, et al. eds. Dermatology in general medicine. $7^{\text {th }}$ edn. New York: McGraw-Hill 2008:622-40.

[2] Karen JK, Pomeranz MK. Skin changes and diseases in pregnancy. In: Wolff K, Goldsmith LA, Katz SI, et al. eds. Dermatology in general medicine. $7^{\text {th }}$ edn. New York: McGraw-Hill 2008:955-62.

[3] Vazquez M, Maldonado H, Benaman C, et al. Melasma in men: a clinical and histologic study. Int J Dermatol 1988;27(1):25-7.

[4] Grimes PE. Melasma. Etiologic and therapeutic considerationa. Arch Dermatol 1995;131(12):1453-7.

[5] Kim EH, Kim YC, Lee ES, et al. The vascular characteristics of melasma. J Dermatol Sci 2007;46(2):111-6.
[6] Mahmoud BH, Ruvolo E, Hexsel CL, et al. Impact of long-wavelength UVA and visible light on melanocompetent skin. J Invest Dermatol 2010;130(8):2092-7.

[7] Sanchez NP, Pathak MA, Sato S, et al. A clinical light microscopic, ultrastructural and immunofluorescence study. J Am Acad Dermatol 1981;4(6):698-710.

[8] Gilchrest BA, Fitzpatrick TB, Anderson RR, et al. Localization of melanin pigmentation in the skin with Wood's lamp. Br J Dermatol 1977;96(3):245-8.

[9] Nguyen TH, Rooney JA. Trichloroacetic acid peels. Dermatol Ther 2000;13:173-92.

[10] Kimbrough-Green CK, Griffiths CE, Finkel LJ, et al. Topical retinoic acid (tretinoin) for melasma in black patients. A vehicle-controlled clinical trial. Arch Dermatol 1994;130(6):727-33.

[11] Griffiths CE, Finkel LJ, Ditre CM, et al. Topical tretinoin (retinoic acid) improves melasma. A vehiclecontrolled, clinical trial. $\mathrm{Br} J$ Dermatol 1993;129(4):415-21.

[12] Kalla G, Garg A, Kachhawa D. Chemical peeling-glycolic acid versus trichloroacetic acid in melasma. Indian J Dermatol Venereol Leprol 2001;67(2):82-4.

[13] Dogra A, Gupta S, Gupta S. Comparative efficacy of $20 \%$ trichloroacetic acid and $50 \%$ glycolic acid peels in treatment of recalcitrant melasma. J Pak Assoc Derma 2006;16:79-85. 